\title{
"Research and methodological basis for ensuring the financial security of banks in Ukraine"
}

\begin{tabular}{|c|c|}
\hline \multirow{5}{*}{ AUTHORS } & levgen Balatskyi (D https://orcid.org/0000-0001-7039-1009 \\
\hline & $\mathbb{R}$ https://publons.com/researcher/2455239/ievgen-balatskyi/ \\
\hline & Vita Andrieieva (D https://orcid.org/0000-0002-6357-3063 \\
\hline & Olesia Solodovnik (D) https://orcid.org/0000-0002-0636-533X \\
\hline & Volodymyr Lypchanskyi (D https://orcid.org/0000-0002-8525-512X \\
\hline ARTICLE INFO & $\begin{array}{l}\text { levgen Balatskyi, Vita Andrieieva, Olesia Solodovnik and Volodymyr } \\
\text { Lypchanskyi (2018). Research and methodological basis for ensuring the } \\
\text { financial security of banks in Ukraine. Banks and Bank Systems, 13(4), 143-152. } \\
\text { doi:10.21511/bbs.13(4).2018.13 }\end{array}$ \\
\hline DOI & http://dx.doi.org/10.21511/bbs.13(4).2018.13 \\
\hline RELEASED ON & Wednesday, 26 December 2018 \\
\hline RECEIVED ON & Tuesday, 30 October 2018 \\
\hline \multirow[t]{2}{*}{ ACCEPTED ON } & Tuesday, 25 December 2018 \\
\hline & $((\mathrm{c})$ EY \\
\hline LICENSE & $\begin{array}{l}\text { This work is licensed under a Creative Commons Attribution } 4.0 \text { International } \\
\text { License }\end{array}$ \\
\hline JOURNAL & "Banks and Bank Systems" \\
\hline ISSN PRINT & $1816-7403$ \\
\hline ISSN ONLINE & $1991-7074$ \\
\hline PUBLISHER & LLC "Consulting Publishing Company "Business Perspectives" \\
\hline FOUNDER & LLC “Consulting Publishing Company "Business Perspectives" \\
\hline
\end{tabular}

NUMBER OF REFERENCES

32

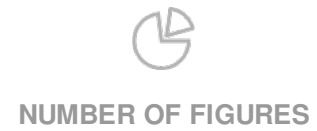

3
NUMBER OF TABLES

0

(C) The author(s) 2021. This publication is an open access article. 


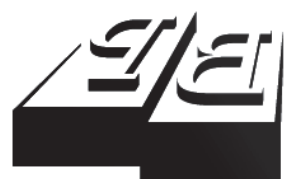

BUSINESS PERSPECTIVES

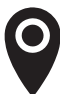

LLC "CPC "Business Perspectives" Hryhorii Skovoroda lane, 10, Sumy, 40022, Ukraine

www.businessperspectives.org

Received on: $30^{\text {th }}$ of October, 2018 Accepted on: $25^{\text {th }}$ of December, 2018

(c) Ievgen Balatskyi, Vita Andrieieva Olesia Solodovnik, Volodymyr Lypchanskyi, 2018

Ievgen Balatskyi, Ph.D., Associate Professor, Sumy State University, Ukraine.

Vita Andrieieva, Ph.D., Associate Professor, Department of Theoretical and Applied Economics, "KROK" University, Kyiv, Ukraine.

Olesia Solodovnik, Ph.D., Associate Professor, Department of Finance and Credit, Kharkiv National University of Civil Engineering and Architecture, Ukraine.

Volodymyr Lypchanskyi, Ph.D., Associate Professor, Department of Economy, management and Commercial Activity, Central Ukrainian National Technical University, Ukraine.

\section{(ㄷ) (1)}

This is an Open Access article, distributed under the terms of the Creative Commons Attribution 4.0 International license, which permits unrestricted re-use, distribution, and reproduction in any medium provided the original work is properly cited.
Ievgen Balatskyi (Ukraine), Vita Andrieieva (Ukraine), Olesia Solodovnik (Ukraine), Volodymyr Lypchanskyi (Ukraine)

\section{RESEARCH AND}

METHODOLOGICAL BASIS

FOR ENSURING THE FINANCIAL SECURITY OF BANKS IN UKRAINE

\begin{abstract}
In an unstable financial and economic, political and social context, a number of Ukrainian banks demonstrate downtrends in their profitability, liquidity, and solvency rates. With that, the financial health and the growth vector of the whole banking sector of the country in the strategic perspective precisely depends on the quality of measures taken to ensure the financial security of a banking institution.

The article analyzes the concept of financial security of a bank from the standpoint of protective, dynamic, resource-functional, competitive and systemic approaches. The authors substantiate that the financial security of the banking system as a whole and that of an individual bank is an integral part of the financial security of the country. In addition, three methodological approaches to assessing the financial security of the country's banking sector are identified and described, namely instrumental, system and target-oriented and criterial ones. Based on theoretical and methodological analysis of scientific works and methodological approaches, a system of research and methodological support for the bank's financial security is proposed.
\end{abstract}

Keywords

JEL Classification bank, security, assessment, financial security, methodical approach, financial security of the bank

\section{INTRODUCTION}

The globalization processes activation, the expansion of foreign capital, the aggravation of the financial and economic crisis and the increase in competition between banking institutions have a significant impact on their activities and financial results and determine their long-term functioning.

One of the key aspects of a successful and profitable activity of a bank is to ensure its financial security, which depends on the volume and sources of its resource base, credit investment and deposit activity, income and expenditure management policies. The financial security of a banking institution is an integral part of both the security of the country's banking sector and the financial security of the state as a whole. The need to ensure a high level of financial security of the bank necessitates an integrated approach by developing and deepening the research and methodological basis for its provision considering the influence of internal and external threats. The need to develop effective methodological tools is due to the fact that during 2014-2017 there was a rapid increase in the number of insolvent banks in Ukraine. Such a negative trend in the banking sector development generates macroeconomic problems accompanied by a decrease in potential depositors' confidence in banking institutions, as well as a lack of credit resources for borrowers. 
Thus, nowadays, developing research basis and methodological approaches to provide an effective system of financial security of a banking institution becomes especially relevant.

\section{THEORETICAL BASIS}

The issues of ensuring the economic and financial security of Ukraine, its banking system, as well as an individual banking institution are becoming increasingly relevant due to high political risks, instability in foreign economic policy, increasing the size of government debt and dependence on world credit institutions and financial assistance from other countries.

In Ukraine, these issues are examined in legislative and regulatory documents and in the scientific plane as well.

In particular, the Order "On Approval of the Methodology for Calculating the Level of Economic Security of Ukraine" No. 60 dated March 2, 2007 (The Ministry of Economy of Ukraine, n. d.) and the Order "On Approval of Methodological Recommendations for Calculating the Level of Economic Security of Ukraine" No. 1277 as from October 29, 2013 (The Ministry of Economic Development and Trade of Ukraine, n. d.) approved the recommendations for calculating the indicators of the economic security of Ukraine and the methodology for shaping a set of indicators.

The Law of Ukraine "On National Security of Ukraine" dated June 21, 2018 (The Verkhovna Rada of Ukraine, 2018) defines the basis for the state policy and the key principles of national security.

The Order of the Cabinet of Ministers of Ukraine "On Approval of the Concept for the Safeguarding of National Security in the Financial Sphere" as of August 15, 2012, No. 569-p, highlights the key problems of national security that require to be resolved and identifies ways to achieve this (Cabinet of Ministers of Ukraine, 2012).

Recommendations on the shaping an effective system of public finance management and improving Ukraine's financial security indicators are specified in the Order of the Cabinet of
Ministers of Ukraine "On Approving the Strategy for Reforming the Public Finance Management System for 2017-2020" No. 142-r dated February 8, 2017 (Cabinet of Ministers of Ukraine, n. d.).

Despite numerous normative documents dealing with the concept and principles of financial security, there are many different scientific approaches to the issues of forming and ensuring the financial security.

Kolodiziev and Seredina (2010) analyzed the legal framework of Ukraine's financial security and the mechanism for its achievement, highlighted the existing shortcomings and developed their own recommendations for improving the financial security management system.

Kovalchuk (2016) highlighted the institutional constituents and factors influencing financial security of the country. To address the problems in this area, it is proposed to adhere to the principle of transparency and balance of interests of the state and business.

Myronchuk and Panochyshyn (2017) consider the state of financial security in Ukraine and the methodology for its evaluation by the Ministry of Economic Development and Trade of Ukraine and the National Institute for International Security Issues of Ukraine. The authors also highlight the main differences between the two approaches.

Subbotovych and Antropova (2013) identified the main indicators of financial security in terms of components, comparing the experience of Ukraine and some developed countries (USA, Germany, France).

Tyshchenko and Chaibok (2017) consider the idea of the financial stress index, the calculation of which can be one of the anti-crisis measures, since this method helps to track the emergence of crisis phenomena in the financial system.

In the context of the studies conducted, the security of the banking system as a key area of fi- 
nancial security of the country is separately considered, since it determines the country's economic development, social and economic security of the population.

Vovchenko (2016) focused on the issues of improving the banking sector efficiency in order to effectively ensure the financial security of the state. The author offers his own strategy, which is based on the concepts of counteraction, passive protection and an adequate response to challenges and threats in the field of economics and finance. According to the author, the important aspects are the restructuring of the banking sector, the creation of a favorable investment climate in the banking system, and increasing the role of the NBU's monetary policy.

Demirguc-Kunt and Detragiache (1998) determined the reasons of banking crises in developing and developed countries. They found out that financial security of the banking sector strongly influences the whole financial and economic system.

Novickyte and Pedroja (2015) assessed how mergers and acquisitions in banking influence the state financial security and sustainable financial system development.

Kovalenko (2013) considered the issues of securing banking activity. The author highlights and analyzes the components of banking security systems. Particular attention is paid to the challenges that a separate banking institution may face.

Malakhova (2017) highlights the position of banking security in the overall national security system of the country and proposes her own approach to regulating banking activity as a component of financial security. To solve problems in the banking sector, it is proposed to reduce the refinancing rate to the level of the average rate of profitability in industry, use anti-crisis currency control, refuse to guarantee foreign currency deposits.

Bednarski and Osinski (2002) investigated the issues in financial and banking sector of Poland. They proved that financial security of the separate bank impacts the whole bank system of the country.

Vasylchyshyn (2016) compared various methods of assessing the financial security of the bank- ing system and identified the most universal models that can be effectively used in Ukraine. The author highlights a methodology that takes into account the indicators of internal and external security of banks, namely: asset quality, credit risk ratios, currency risk, budget deficit, etc.

Shtefan (2018) thoroughly analyzed the financial security indicators of the banking sector. The author emphasizes the lack of clear normative values of financial security in the banking sector. He also predicts the unprofitableness of the banking system in 2019 as a result of a decrease in operating income and an increase in banks' expenses on the creation of reserves.

Chiarlone (2007) investigated, analyzed and compared the problems of bank financial security in Asian and European bank systems.

Emphasizing the individual bank security as a component of the financial security of the banking system and the state as a whole is completely justified, since banking institutions have levers of direct influence on the efficient functioning of the investment, financial, manufacturing and other fields of the domestic economy.

Despite a great number of interpretations of the essence of the bank's financial security, this question has not been fully elaborated in the theoretical, methodological and scientific aspects. This necessitates the study and generalization of the conceptual apparatus to clarify its content.

Baryliuk (2016) proposes approaches to improving the organizational and economic mechanism for providing financial security of a commercial bank. The author also identified the relationship between financial security of the bank and financial security of the state.

Bukin (2003), while investigating the issue of ensuring the financial security of the bank, concludes it is primarily the task of owners, shareholders and other stakeholders. The author identifies three main components of financial security of the bank: organizational security, security of banking operations and personnel security. 
Zubok (2002) considers the financial security of a bank as a sustainable living, which ensures the realization of its main interests and priorities, protection from external and internal factors regardless of the operating conditions.

Some scholars regard the financial security of the bank as a dynamic state associated with changes in the internal and external environment of the banking institution. The advantage of this approach is to ensure the focus of the bank's activities on the key aspect of the strategy, namely ensuring stability, protecting financial interests and the ability to generate financial resources influenced by internal and external threats. Baranovskyi $(2006,2012)$ supports this approach defining financial security of the bank as protection of its financial interests, financial stability and the environment in which it operates. He also assesses financial security as a set of conditions under which actions or circumstances potentially dangerous for the bank financial health are warned or reduced to the level, at which they are not able to hinder the established functioning of the bank, the preservation and restoration of its property and infrastructure, as well as to prevent the achievement of its main objectives. According to Yepifanov (2009), financial security is a state of a banking institution characterized by a balance and robustness against the impact of external and internal threats, its ability to achieve its goals and generate sufficient financial resources to ensure sustainable development. Consequently, the aforementioned scholars interpret the financial security of the bank via the effective and functional operations of entities aimed at preventing and neutralizing internal and external threats.

Resource and functional approach to disclosing the essence of financial security of the bank implies the effective use of its resources (potential). Oleinikov (2007) supports this approach. He considers financial security as the most effective use of corporate resources of the bank, which is reflected in the best value indicators of efficiency and effectiveness, quality of management and use of its fixed and working assets, capital structure, rates of dividend payments for securities, as well as the exchange rate of its securities as a synthetic indicator of the current financial status of a commercial bank and prospects for its technological and financial development. The definition of the bank financial security in the context of using available resources is incomplete, since the most important and key characteristic of this category is the financial interests, which, in case of untimely, insufficient and incomplete lack of implementation, may become threats or risks of the bank, an obstacle to securing its financial security.

According to a competitive approach, the level of financial security of a bank is determined based on assessing its competitive advantages in the market when compared to other financial intermediaries and banking institutions due to the correspondence of its resource availability to strategic goals and objectives. Vovchenko (2014) notes that the key objective of financial security is to ensure the competitiveness of both a bank and the banking system as a whole in the banking services market and to prevent the possibility of losses or loss of profit as a result of the internal and external threats implementation. Consequently, from the perspective of competitive advantages, financial security of a bank is based on the independence, efficient use of its finances, productivity and profitability, which is achieved according to the developed strategy subject to neutralization of external and internal threats. Effective attraction and use of financial resources of the bank, which ultimately will affect its profitability, are the undeniable advantages of a competitive approach. At the same time, it is believed that the study of financial security exclusively via a combination of competitive advantages is incomplete and does not allow financial security to be fully assessed, since it serves only as one of the criteria of this concept.

Systemic approach is an alternative method for determining the financial security of a bank. It implies the following: when solving the issue of ensuring the financial security of the bank, its functioning, the activities of employees, as well as the impact of both internal and external threats are considered as a dynamic system, which takes together its links in terms of sustainability and self-development. According to Yevchenko (2009), financial security of a bank can be considered as its financial status, which is characterized by a balanced system of financial indicators, resistance to internal and external threats, which allows timely and full implementation of the commitments, 
provides its effective development in the current and subsequent periods.

The protective approach supporters argue that the financial security of the bank is determined, firstly, as a condition under which financial sustainability and financial interests are protected from destructive factors of both external and internal environments. Secondly, the bank shapes such behavior in the market that would allow it to function effectively and achieve its goals influenced by constant internal and external threats (Baryliuk, 2016; Khytrin, 2004).

\section{RESULTS}

It is believed that considering the banking institution security as a component of the financial security of the state is well founded, because, firstly, banks have levers of direct influence on the efficient functioning of the investment, financial, production and other fields of the domestic econ- omy. Secondly, the volume of money supply, which in turn directly affects the functioning of the real and financial economy sectors depends on the efficient functioning the banking sector. Thus, it can be argued that the status of the banking sector has a significant impact on the level of financial security of the state.

In addition, it is important to note that the security of a particular banking institution has a direct impact on the security of the banking sector, since banks are the financial and credit centers, which affect the domestic economy while carrying out operations for attracting and placing temporarily surplus funds. At the same time, structural changes in the activity of a separate bank, distrust among the population, mass withdrawal of deposits cause negative system-wide consequences. It is also important to realize that it is impossible to achieve the appropriate level of financial security of a single bank without achieving its appropriate indicator at the entire banking system level. It should also be emphasized that there is a logical

Source: Constructed by the authors based on Baryliuk (2016).

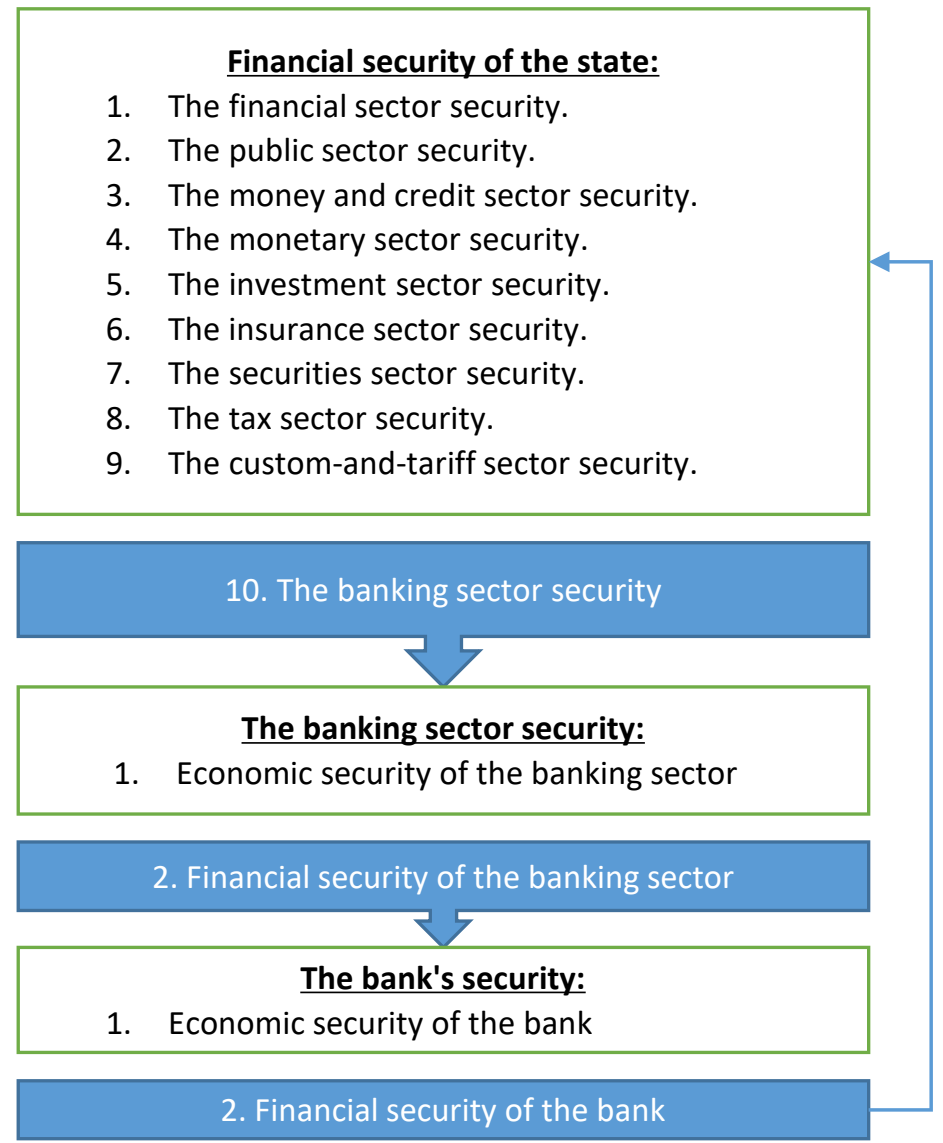

Figure 1. The relationship between financial security of the state and financial security of a bank 
relationship between the financial and economic component of the bank's activity. On the other hand, the importance of considering financial security as a necessary and independent component of ensuring the effective functioning of a banking institution should be highlighted.

Figure 1 formalizes the above-mentioned relationships between financial security of the state, security of the banking sector and financial security of the banking institution.

Ensuring financial security of the banking system is impossible without ensuring its transparent functioning. However, this affects the functioning of the banking sector ambiguously.

On the one hand, it provides for:

- efficient resource allocation in the financial market by eliminating information asymmetry;

- reducing the frequency of banking crises and costs to overcome these crises;

- fast recovery of troubled banks in the post-crisis period;

- maintaining high market discipline and banking culture.

On the other hand, a number of negative aspects exist in terms of the banking sector transparency, namely: the risk of bank destabilization after disclosure;

open banks may be more exposed to depositors panic than closed ones;

- transparent banks' securities rates are more volatile;

- the banking sector transparency stimulates the process of disintermediation, that is, the "direct" entry of the borrower into the financial market and the removal of the intermediary from the market.

It is advisable to use methodological approaches that provide a comprehensive analysis with further assessment of the financial security of the state's banking sector, taking its transparency into account (Figure 2).

Thus, the authors have identified and characterized three methodological approaches to assessing the financial security of the banking sector of the country, namely: instrumental, systemic and target-oriented and criterial ones.

Based on theoretical and methodological analysis of scientific works and methodological approaches, a system of research and methodological support for the bank's financial security is proposed (see Figure 3).

Figure 3 shows the influence of external and internal factors on the financial security of the bank.

Source: Constructed by the authors based on Vovchenko (2016).

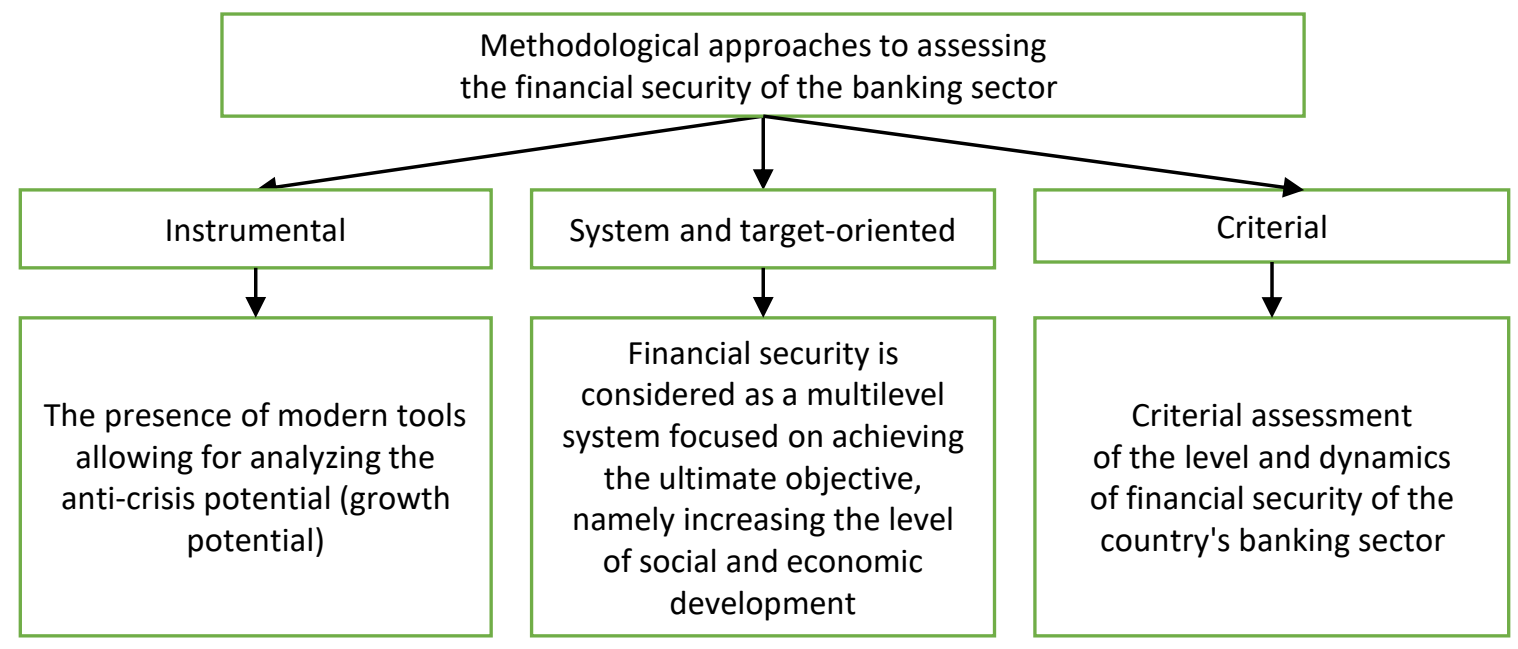

Figure 2. Methodological approaches to assessing the financial security of the banking sector 


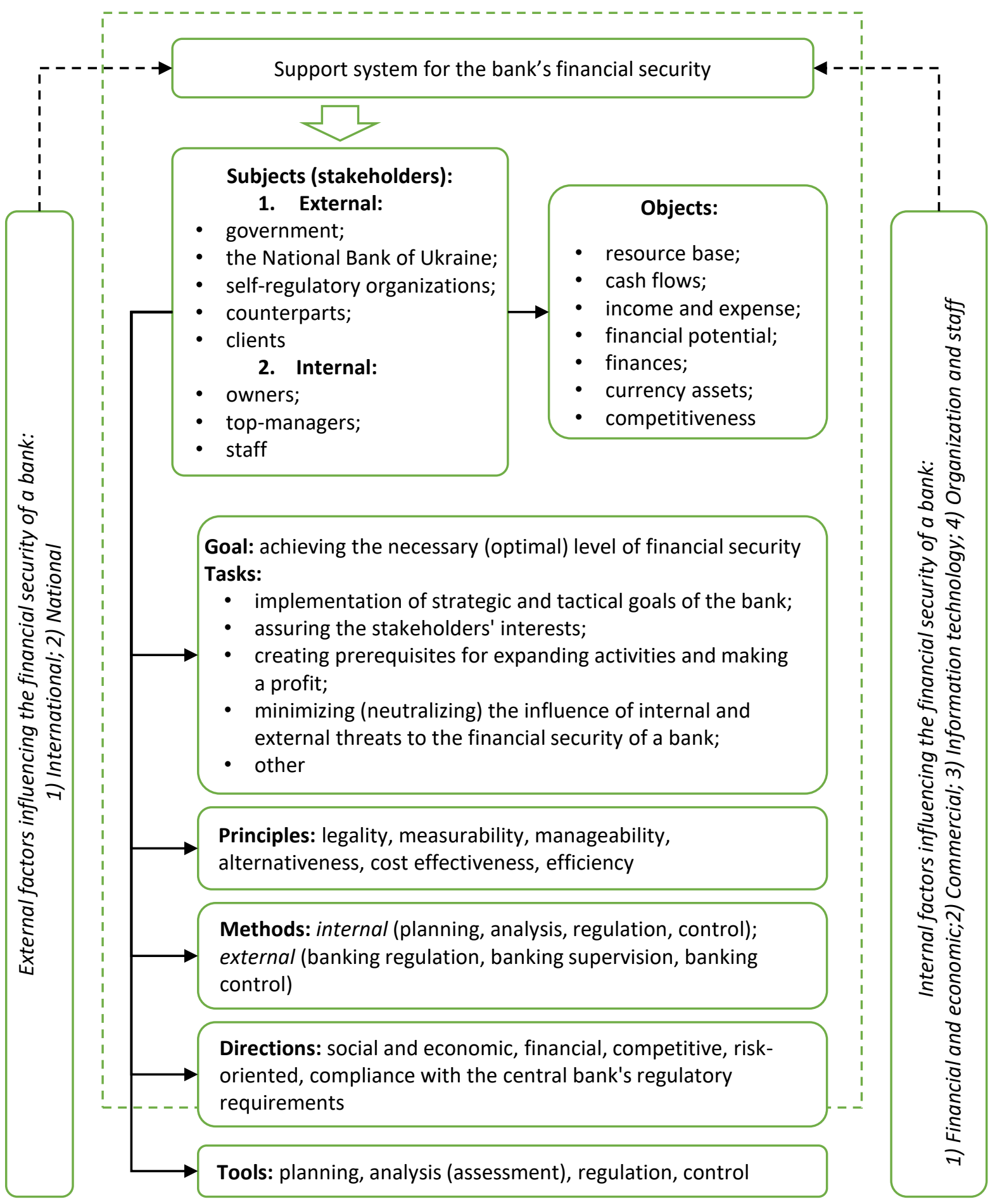

Figure 3. The system of research and methodological support for financial security of a bank

External factors include the factors of the interna- The subjects of the financial security of the banktional environment and those of the national en- ing institution include its internal and external vironment. Internal factors include financial and stakeholders. The objects are the resource base economic, commercial, information and techno- of the bank, its cash flows and financial potential, logical and organizational-personnel factors. funds in national and foreign currency. Separately, 
the competitiveness of the bank is highlighted as one of the most important features of its activities.

The purpose of ensuring the financial security of the bank is, first of all, the need to achieve its required level, based on both the regulatory values set by the regulator and the current market situation.

The authors highlight a set of tasks for the above-mentioned goal implementation, which are as follows:

- achieving strategic and tactical goals of the bank;

- assuring the interests of internal and external stakeholders;

- creating prerequisites for expanding activities and making a profit;

- minimizing (neutralizing) the influence of internal and external threats to the financial security of the bank, etc.

The basic principles for ensuring the financial security of the banking institution are high- lighted, namely legality, measurability, manageability, alternativeness, effectiveness and efficiency.

The main internal methods for ensuring the financial security of the bank include financial planning, financial analysis, financial regulation and financial control. The main external methods of ensuring the financial security of the bank are: banking regulation, banking supervision and banking control.

The tools for ensuring financial security of a bank include:

- planning (financial plan and operations schedule, bank budget, and forecast indicators for the activity);

- $\quad$ analysis (preliminary, operational, final, and perspective);

- regulation (profitability management, risk management, liquidity management);

control (strategic, current, effective).

\section{DISCUSSION AND CONCLUSION}

The financial security of a bank is an integral part of the financial and, hence, national security of the state. It is a status of a banking institution characterized by a balance and robustness against the influence of external and internal threats, its ability to achieve goals and generate sufficient financial resources to assure sustainable development. Consequently, the financial security system needs to be integrated into the bank management system, which will ensure the continuous control of risks and making timely and sound decisions.

Banks have levers of direct influence on the efficient functioning of investment, financial, manufacturing and other spheres of the national economy, and the volume of money supply depends on the banking sector efficiency, which in turn directly affects the functioning of the real and financial sectors of the country's economy. From there, the usefulness of highlighting the banking institution security as a component of financial security of the state's banking sector is substantiated. In order to formalize the above-mentioned relationships between financial security of the state, security of the banking sector and financial security of the banking institution, the corresponding structural and logical scheme has been constructed.

In order to ensure the financial security of the banking system, three methodological approaches to assessing the financial security of the country's banking sector are identified, namely: instrumental, system and target-oriented and criterial approaches. Each approach has its own characteristics and can be used both individually and taken as a whole. 
Based on the analysis of research articles and methodological approaches, a system of research and methodological support for the bank's financial security is proposed. The subject and object interconnections and both external and internal impact factors were identified.

\section{REFERENCES}

1. Baranovskyi, О. (2014). Специфіка фінансової безпеки в банківській сфері [Spetsyfika finansovoi bezpeky v bankivskii sferi]. Visnyk Natsionalnoho banku Ukrainy, September, 17-23. Retrieved from http:// www.irbis-nbuv.gov.ua/cgi-bin/ irbis_nbuv/cgiirbis_64.exe?I21 $\mathrm{DBN}=\mathrm{LINK} \& \mathrm{P} 21 \mathrm{DBN}=\mathrm{UJRN}$ $\& Z 21 \mathrm{ID}=\& S 21 \mathrm{REF}=10 \& S 21 \mathrm{C}$ $\mathrm{NR}=20 \& S 21 \mathrm{STN}=1 \& \mathrm{~S} 21 \mathrm{FMT}$ $=\mathrm{ASP} \_$meta\&C21COM=S\&2 S21P03 $=$ FILA $=\& 2$ S21STR=Vnbu_2014_9_15

2. Baranovskyi, O. I. (2006). Банківська безпека: проблема виміру [Bankivska bezpeka: problema vymiru]. Ekonomika $i$ prohnozuvannia, 1, 7-26.

3. Baryliuk, M.-M. R. (2015). Діагностика стану забезпечення фінансової безпеки комерційного банку в Україні [Diahnostyka stanu zabezpechennia finansovoi bezpeky komertsiinoho banku v Ukraini]. Visnyk ONU, 20(4), 199-205.

4. Baryliuk, M.-M. R. (2016). Організаційно-економічний механізм забезпечення фінансової безпеки комерційного банку [Orhanizatsino-ekonomichnyi mekhanizm zabezpechennia finansovoi bezpeky komertsiinoho banku]. Biznes Inform, 11, 261-270.

5. Bednarski, P., \& Osinski, J. (2002). Financial Sector Issues in Poland. In C. Thimann (Ed.), Financial Sector in EU Accession Countries. Frankfurt: ECB.

6. Bukin, S. (2003). Безопасность банка [Bezopasnost banka]. Bankovskiye tekhnologii, 9, 8-15. Retreived from www.bizcom.ru/ security/ 2003-09/01.html

7. Cabinet of Ministers of Ukraine. (2012). Розпорядження Кабінету Міністрів України Про схвалення Конщепції забезпечення начіональної безпеки у бінансовій сфері від 15 серпня 2012 р. № 569-р [Rozporiadzhennia Kabinetu Ministriv Ukrainy Pro skhvalennia Kontseptsii zabezpechennia natsionalnoi bezpeky u finansovii sferi vid 15 serpnia 2012 r. No. 569p]. Retrieved from http://zakon2. rada.gov.ua/laws/show/569-2012$\% \mathrm{D} 1 \% 80$

8. Cabinet of Ministers of Ukraine. (n. d.). Розпорядження Кабінету Міністрів України Про схвалення Стратегіі реформування системи управління державними фінансами на 2017-2020 роки № 142-p від 8 лютого 2017 p. [Rozporiadzhennia Kabinetu Ministriv Ukrainy Pro skhvalennia Stratehii reformuvannia systemy upravlinnia derzhavnymy finansamy na 2017-2020 roky No. 142-p vid 8 liutoho 2017 r.]. Retrieved from https://www.kmu. gov.ua/ua/npas/249797370

9. Chiarlone, S. (2007). The New Asian Banking System. Europe and Asia Strategies. EAST (Europe and Asia Strategies), 17(December), 182-189.

10. Demirguc-Kunt, A., \& Detragiache, E. (1998). The Determinants of Banking Crises in Developing and Developed Countries. IMF Staff Papers, 45(1).

11. Khytrin, O. I. (2004). Фінансова безпека комерційних банків [Finansova bezpeka komertsiinykh bankiv]. Finansy Ukrainy, 11, 118-124.

12. Kolodiziev, O. M., \& Seredina, A. V. (2010). Державна система управління фінансовою безпекою України та правові засади iii функціонування [Derzhavna systema upravlinnia finansovoiu bezpekoiu Ukrainy ta pravovi zasady yii funktsionuvannia]. In Проблеми і перспективи розвитку банківської системи Украӥни: збірник наукових nраць [Problemy i perspektyvy rozvytku bankivskoi systemy Ukrainy: zbirnyk naukovykh prats] (pp. 383-398). Derzhavnyi vyshchyi navchalnyi zaklad "Ukrainska akademiia bankivskoi spravy Natsionalnoho banku Ukrainy". Retrieved from http://r250.sudu.edu.ua/bitstream/123456789/55976/5/Kolodiziev_Derzhavna_systema.pdf

13. Kostiuchenko, O. Ye., \& Patalakh, V. I. (2014). Забезпечення фінансової безпеки банківської системи як складова фінансової безпеки держави [Zabezpechennia finansovoi bezpeky bankivskoi systemy yak skladova finansovoi bezpeky derzhavy]. Naukovyi visnyk Khersonskoho derzhavnoho universytetu, Seriia Ekonomichni nauky, 7(5), 24-27. Retrieved from http://www.ej.kherson.ua/journal/ economic_07/224.pdf

14. Kovalchuk, M. V. (2016). Інституціональні складові фінансової безпеки держави [Instytutsionalni skladovi finansovoi bezpeky derzhavy] Ekonomicha nauka, 7, 88-93. Retrieved from http://www. economy.in.ua/pdf/7_2016/19.pdf

15. Kovalenko, V. V. (2013). Концептуальні основи формування системи безпеки банківської діяльності [Kontseptualni osnovy formuvannia systemu bezpeky bankivskoi diialnosti]. Ekonomichnyi chasopys, XXI, 1-2(1), 56-59. Retrieved from http://dspace.oneu.edu.ua/jspui/ handle/123456789/1148

16. Malakhova, O. L. (2017). Peгулювання діяльності банків у контексті забезпечення фінансової безпеки держави [Rehuliuvannia diialnosti bankiv u konteksti zabezpechennia 
finansovoi bezpeky derzhavy]. Hlobalni ta natsionalni problem ekonomiky, 17, 684-691. Retrieved from http://global-national.in.ua/ archive/17-2017/140.pdf

17. Myronchuk, V. M., \& Panochyshyn, Yu. M. (2017). Оцінка рівня фінансової безпеки в Україні [Otsinka rivnia finansovoi bezpeky v Ukraini]. Naukovyi visnyk Uzhhorodskoho natsionalnoho universytetu, Seriia: Mizhanrodni ekonomichni vidnosyny ta svitove hospodarstvo, 13(2). Retrieved from http://www. visnyk-econom.uzhnu.uz.ua/ archive/13_2_2017ua/9.pdf

18. Novickyte, L., \& Pedroja, G. (2015). Assessment of mergers and acquisitions in banking on small open economy as sustainable domestic fi nancial system development. Economics and Sociology, 8(1), 72-88. http:// dx.doi.org/10.14254/2071789X.2015/8-1/6

19. Oleynikov, Ye. A. (Ed.). (2007). Основы экономической безопасности (Государство, регион, предприятие, личность) [Osnovy ekonomicheskoy bezopasnosti (Gosudarstvo, region, predpriyatiye, lichnost)] (288 p.). Moscow.

20. Shtefan, L. B. (2018). Аналіз деяких індикаторів фінансової безпеки банківської системи Україні [Analiz deiakykh indykatoriv finansovoi bezpeky bankivskoi systemy Ukrainy]. Ekonomika i suspilstvo, 16, 862-870. Retrieved from http:// economyandsociety.in.ua/journal/16_ukr/131.pdf

21. Subbotovych, Yu., \& Antropova, O. (2013). Індикатори фінансової безпеки України [Indykatory finansovoi bezpeky Ukrainy]. Svit finansiv, 2, 144-151. Retrieved from http://dspace.tneu.edu.ua/bit stream/316497/10024/1/\%D0\%A1 \%D1\%83\%D0\%B1\%D0\%B1\%D0\% BE\%D1\%82\%D0\%BE\%D0\%B2\%D 0\%B8\%D1\%87\%20\%D0\%AE..pdf

22. The Ministry of Economic Development and Trade of Ukraine. (n. d.). Наказ Про затвердження Методичних рекомендацій щодо розрахунку рівня економічної безпеки України № 1277 від 29.10.2013

[Nakaz Pro zatverdzhennia Metodychnykh rekomendatsii shchodo rozrakhunku rivnia ekonomichnoi bezpeky Ukrainy No. 1277 vid 29.10.2013]. Retrieved from http://zakon.rada.gov.ua/ rada/show/v1277731-13

23. The Ministry of Economy of Ukraine (n. d.). Наказ Про затвердження Методики розрахунку рівня економічної безпеки України № 60 від 02.03.2007 [Nakaz Pro zatverdzhennia Metodyky rosrakhunku rivnia ekonomichnoi bezpeky Ukrainy No. 60 vid 02.03.2007]. Retrieved from http:// zakon.rada.gov.ua/rada/show/ v0060665-07

24. The Verkhovna Rada of Ukraine (2018). Закон України Про національну безпеку України вid 21.06.2018 [Zakon Ukrainy Pro natsionalnu bezpeku Ukrainy vid 21.06.2018]. Retrieved from http://zakon.rada.gov.ua/laws/ show/2469-19

25. The Verkhovna Rada of Ukraine (n. d.). Закон України Про засади внутрішньої $i$ зовнішньої політики. Редакція вid 08.07.2018 [Zakon Ukrainy Pro zasady vnutrishnioi $i$ zovnishnioi polityky. Redaktsiia vid 08.07.2018]. Retrieved from http://zakon5.rada.gov.ua/laws/ show/2411-17

26. Tyshchenko, L., \& Chaibok, A. (2017, June). Індекс фінансового стресу для України [Indeks finansovoho stresu dlia Ukrainy]. Visnyk Natsionalnoho banku Ukrainy. Retrieved from https://bank.gov.ua/doccatalog/ document?id=53082662

27. Vasylchyshyn, O. В. (2016). Аналіз наявних моделей оцінки фінансової безпеки банків і банківської системи і напрями їх удосконалення [Analiz naiavnykh modelei otsinky finansovoi bezpeky bankiv bankivskoi systemy i napriamy yikh udoskonalennia]. Rehionalna ekonomika, 2, 156-164. Retrieved from http://ird.gov.ua/pe/ re201602/re201602_156_VasylchyshynOB.pdf

28. Vovchenko, R. S. (2014). Забезпечення фінансової безпеки банківського сектору економіки України [Zabeazpechennia finansovoi bezpeky bankivskoho sektoru ekonomiky Ukrainy]. In Проблеми забезпечення ефективного функиіонування та стабільного розвитку банківської системи України: тези доповідей учасників IV науково-практичноі конференції студентів, аспірантів та молодих вчених [Problemy zabezpechennia efektyvnoho funktsionuvannia ta stabilnoho rozvytku bankivskoi systemy Ukrainy: tezy dopovidei uchasnykiv IV naukovopraktychnoi konferentsii studentiv, aspirantiv ta molodykh vchenykh] (pp. 23-25). Kyiv: University of Banking of Ukraine.

29. Vovchenko, R. S. (2016). Фінансова безпека банківського сектору економіки України [Finansova bezpeka bankivskoho sektoru ekonomiky Ukrainy] (Ph.D. (Economics) thesis). Retrieved from http://ubs.edu.ua/images/ $\mathrm{PDF} /$ vovchenkodisser.pdf

30. Yepifanov, A. O. (Ed.), Plastun, O. L., Dombrodskyi, V. S. et al. (2009). Фінансова безпека підприємств і банківських установ [Finansova bezpeka pidpryiemstv i bankivskykh ustanov] (295 p.). Sumy: DVNZ "Ukrainska akademiia bankivskoi spravy Natsionalnoho banku Ukrainy".

31. Yevchenko, N. H., \& Kryklii, O. А. (2009). Вплив податкових ризиків на фінансову безпеку банку [Vplyv podatkovykh ryzykiv na finansovu bezpeku banku]. Problemy i perspektyvy rozvytku bankivskoi systemy Ukrainy, 25, 45-52.

32. Zubok, M. I. (2002). Безпека банківської діяльності [Bezpeka bankivskoi diialnosti] (190 p.). Kyiv: KNEU. 